Please quote as: Leimeister, J. M. \& Krcmar, H. (2005): Evaluation of a systematic design for a virtual patient community. In: Journal of Computer-Mediated Communication (JCMC), Ausgabe/Number: 4, Vol. 10, Erscheinungsjahr/Year: 2005. 


\title{
EVALUATION OF A SYSTEMATIC DESIGN FOR A VIRTUAL PATIENT COMMUNITY
}

\author{
Author: Jan Marco Leimeister, Helmut Krcmar \\ Affiliation: Information Systems (I 17), Technische Universität München \\ Email addresses: \{leimeister; krcmar\}@in.tum.de
}

\begin{abstract}
Virtual Communities (VCs) offer ubiquitous access to information and exchange possibilities for people in similar situations. This is especially valuable for patients with chronic / life-threatening diseases as they have strong needs for information and interaction with peers. It is seldom considered possible to create VCs systematically. Grounded on previous findings, systematic design of the VC krebsgemeinschaft.de (a VC for cancer patients in the German speaking internet) this article describes the evaluation of the design elements and factors which contributed to the VCs success by assessing user acceptance and usage of the site. Additionally, the existence of trust (a constituent element of working VCs) in krebsgemeinschaft.de is addressed. Based on these criteria we verify empirically the chosen design components and generate insights as to the systematic development and operation of VCs in general and for VCs for patients in the German healthcare system in particular.
\end{abstract}

Keywords: Virtual Community, patients, community-building, evaluation, community design.

\section{Introduction 1}

„Perhaps the biggest single misconception about virtual communities is that they can be created" (Shafer ${ }^{2}$ 1999)

1 This paper is a substantially revised and extended version of (Leimeister/Krcmar 2005).

2 Dan Shafer, former senior co-editor of the Online Community Report, founder of WeTalk Network and two Online Communities: Salon.com's Table Talk and CNet Networks Inc.'s Builder.com in an interview with Computerworld in 
As this quote exemplifies, scepticism exists as to whether or not it is possible to systematically create a Virtual Community (VC). Community-building, characterized by the systematic design, implementation and operation of a $\mathrm{VC}$ challenges this assertion. This article describes the assessment of a systematically designed, implemented and operated VC for cancer patients in the German speaking internet. We evaluate the underlying design elements and success factors by measuring user acceptance and usage of the site as well as the existence of trust among users in the VC. The current analysis is based on preceding work on the systematic and user-orientated design of the Virtual Community krebsgemeinschaft.de (Arnold/ Leimeister/Krcmar 2003; Leimeister 2004; Leimeister/Daum/Krcmar 2002).

After a brief description of the potentials of VCs and the situation of patients in Germany we outline the potential benefits of a VC for this user group. We then summarise the central design elements as well as the specific characteristics of these elements for the case of krebsgemeinschaft.de. Based on this, the acceptance and utility of the site are evaluated. The paper concludes with the implications of the findings for the chosen design approach as well as for community-building in general.

\section{Potentials of VCs for patients}

The internet is changing the way people access health-related information and how they search for support and interaction with peers in similar situations. According to the Pew Internet and Life Project, by 2002 more than 73 million US-citizens have searched for health-related information on the web. Health information is one of the most important and fastest growing subjects in the internet. Similar findings are being reported from Europe.

In the traditional healthcare system, existing information services are commonly bound to specific opening hours. Further, information gathering requires the physical presence of the patient or family member. Another source of information for patients and families is conventional support-groups. The usefulness of obtaining information through participation in a self-help group is also dependent on the information seekers' ability to physically be present at a designated place at a designated time. Internet services however are not restrictive in this way and are therefore especially appealing to those who will not or can not leave their home for any number of reasons.

For these groups of people, online communities can be very promising and fruitful for patients seeking information, support and the opportunity to network with persons in similar situations. VCs can free patients from time and space barriers. Information-related potentials of VCs include up-to-datedness of information, anonymity of information usage and needs-based coverage of patient information demands. Additional benefits include the interactivity-related aspects such as empathy among peers and consequently the empowerment of patients through VCs.

December 1999. 


\subsection{Information-related potentials}

The up-to-datedness of information in the internet can often be more timely compared to other forms of media. Considering the importance of health-related information and the amounts of information being continually generated, the internet has a crucial advantage over other media forms especially print publications. New research findings and current developments are available much faster through the internet. In terms of lay information and communication, it can be presumed that there is a higher degree of openness among people interacting via the internet than in face-to-face situations. This openness, especially concerning difficult topics such as lifethreatening diseases or taboo themes has been attributed to the anonymity existing between users of the internet (Döring 2003). A quote from Anja Forbringer, herself a cancer survivor, illustrates this point: „It is not easy for me to speak about the "problem cancer". The more anonymous internet is a great help".

The fit between information supply and demand can be much higher on the internet as the user can compose single modules according to his personal wishes or needs. He/she can, for example, decide on which topic he/she wants to be informed and at which point in time. From a supply standpoint, it is important to remember that the requirements for the presentation of information on the internet are different than those applied to information presented in print format.

\subsection{Interactivity-related potentials}

The internet with its different services offers multi-lateral interaction possibilities. The internet integrates a feedback channel and provides collaborative mass communication where all users can simultaneously be the sender and receiver of information (Döring 2003, S. 41f.) (Rafaeli/LaRose 1993).

Interaction within a VC can promote empathy between members $(1999 ; 2000 ; 2001)$ as well as an emotional integration into a community of peers. Empathy can be characterized by three criteria (Levenson/Ruef 1992, S. 234): a) knowing how the other person feels; b) feeling what another person feels; and c) answering/acting according to this feeling for the misery/woe of the other person. The development of a sense of community is considered a fundamental ingredient of a working VC (Blanchard/Markus 2002) and it is often based on the existence of empathy among the members.

The interaction between members generates an information-pool of high credibility since it is built upon the often extensive experience of members (Schubert 1999, S. 100, Peppers/Rogers 1997, S. 244). The existence of such VCs can lead to an information asymmetry in favour of the members and contribute to the empowerment of patients. The members of a VC might reach a higher market potential and simultaneously a higher market power (Lechner/Schmid 2001) (Schubert 1999, S. 99) for patients in the healthcare system.

In order to be able to design a VC for patients systematically, it is important to understand the situation of cancer patients and their specific needs. Following we summarise some relevant aspects (further details see also Leimeister/Daum/Krcmar, 2002 and Leimeister, 2004). 


\section{General conditions and circumstances for cancer patients}

Cancer is the second most frequent cause of death in Germany. Approximately 338000 people are newly affected every year (Deutsche Krebshilfe 2003). Astonishing, until 2001 almost no information or interaction sites for cancer patients could be found on the German-speaking internet (Daum et al. 2001). Starting there, a community for patients with cancer was developed, introduced, and operated within the $\mathrm{COSMOS}^{3}$-research project.

\subsection{Needs of cancer patients}

The diagnosis "cancer" hits most patients completely unprepared. The often tedious treatmentcycles dominate the daily routine and life-planning of the affected persons. Due to crucial changes in every day, prospectives and priorities change. Provoked by the life-threatening diagnosis, the patient often falls into a psychological crisis. This kind of crisis causes a strong demand for sense-making processes concerning the new situation (Madara 1997).

In order to better cope with a diagnosis of cancer, patients and family members need information on what cancer exactly implies. But this search for information is only one part of the coping-process. Besides the longing for knowledge there can also be a demand for understanding and emotional support from other similarly affected persons. Furthermore, the wish for interaction and communication with peers can emerge as research on coping mechanisms of cancer patients has shown (see e.g. (Leydon, G. M.et al 2000)).

\subsubsection{Information needs}

Cancer patients often have a high demand for information, especially after diagnosis or during therapy (Bilodeau/Degner 1996; Brockopp et al. 1989; Derdiarian 1987; Hinds/Streater/Mood 1995; McCaughan/Thompson 1995; Mills/Sullivan 1999). This demand can result from any number of circumstances but may be caused by an asymmetric distribution of information between physician and patient.

The type of information mainly requested has been shown by recent research on the characteristics of the demands of cancer patients. Kaminski et al. (2001) for example identified a strong interest in information from various areas e.g. effects of cancer on other areas of life such as work, family or sexuality (for similar findings see (Bilodeau/Degner 1996; Leydon et al. 2000; McCaughan/Thompson 1995; Shuyler/Knight 2003)). Attending physicians are not often able to satisfy patient requests for information. Survey research on patients and self-help groups as well as analyses of patient requests to medical service providers (Bahrs/Klingenberg 1995; Hiller 2001; Ruprecht 1998) have shown that patients are not only interested in medical competence in the classical sense, but to a great extent in communication and a human dealing with the individual problems of the single patient (Hiller 2001). Mutual acceptance, more emotional care, empathy, holistic treatment as well as higher quality and better cooperation between the various

The research project COSMOS (Community Online Services and Mobile Solutions) is a joint project of the Technische Universität München and $\mathrm{O} 2$ (Germany) $\mathrm{GmbH} \&$ Co. OHG. The project is supported by the Ministry of Education and Research FKZ 01 HW 0107 -0110. Further information can be found under http://www.cosmos-community.org 
health care professions involved in the treatment process are mentioned as potential fields for improvement.

\subsubsection{Demand for interaction}

When dealing with affected persons, one can often feel their inner wish for empathy and interpersonal interaction. Interaction with people with the same background/disease can play an important role for patients (Forbiger 2001). Their demands are not restricted to attaining pure facts, but also include a need to communicate first hand experiences which are derived from experienced symptoms and interpreted for their individual situation (c.f. (Ferber 1987; Mills/Sullivan 1999; Moeller 1996; SEKIS 2000)). In order to cope with the new situation or to discuss treatment possibilities, the affected person needs one or more interlocutors. There exists an intense interest in similar cases and experiences of others (Bilodeau/Degner 1996; Lieberman et al. 2003; Manaszewicz/Williamson/McKemmish 2002).

Not all cancer patients seek information and interaction. The literature demonstrates, however, that those who do actively cope with their situation by means of interaction and information seeking experience less depression and fear, express fewer complaints, are better integrated socially and often even make better progress in their healing process (McPherson/Higginson/Hearn 2001; Zemore/Shepel 1987; Ziegler/Müller/Grünwald 1986; Ziegler/Pulwer/Koloczek 1984)).

\subsection{Legal framework for internet-based medical services in Germany}

The public health system in Germany is a highly regulated sector. Health care professionals are subject to special conditions and rules of their professional group and/or the organisation's specific legal form. Medical information services on the internet are subject to the general legislation of internet services although there are few specific rules to be considered for offers with medical content (Dierks/Nitz/Grau 2003, S. 95).

Of special interest are the following points: The legal liability for the content of external websites (linking to other parties' content); the consideration of the medical profession's limits and boundaries in form of the differentiation between information and medical advice; aspects of data security in the context of telematic services; and, specifics for the circulation of scientific information to non-authorized lay persons. This legal framework influences patient internetservices in Germany as it requires for example user- and usage-agreements as well as disclaimers. Furthermore there is a legal restriction that disallows computer-mediated individual medical advisory services. Only physicians are allowed to offer this service following a face-toface consultation with the patient. Thus, only general information services are allowed for German patient information sites on the web. 


\section{Central design elements of a VC for patients - the case of krebsgemeinschaft.de}

Previous research on the user-centric design of a VC for cancer patients revealed several design principles and design elements that were applied systematically in the case of krebsgemeinschaft.de. These principles and elements form the core components of the systematic community building. After a brief presentation, we will evaluate the outcome of the application of these components in Section 5 in order to show if and how the community building was successful. For further details on the community building process and its components see (Leimeister 2004).

Important design elements for a VC for patients include the presentation of content (information services), the functionalities, and the use of trust building components.

Principles of importance throughout entire community building process are the usability and the accessibility of the system. In the following we summarize these design elements and their characteristics for the VC krebsgemeinschaft.de, a VC for breast cancer patients in the Germanspeaking internet.

\subsection{Information services}

The major challenge in the area of information services lies in the amount of editorial and quality assured content on the topic breast cancer for this special VC. There were two major challenges: the transformation of medical terminology to an understandable language and the implementation of a structure for this complex subject. During an iterative development and several rounds of discussions with experts (for background information on VC development to meet cancer patients' information needs see Arnold/Leimeister/Krcmar 2003, Leimeister/Daum/Krcmar 2002) the following categorisation of the content was developed and ranked according to the expected relevance for the users:

a) cancer treatment (therapy, follow-up care); b) identifying cancer (early recognition, diagnostic possibilities); c) cancer research (studies, facts and figures); d) living with cancer (sports, nutrition, family, sexuality); and e) experiences with cancer (reports from affected persons).

The division into main- and sub-categories was intended to help the user to understand the provided information in a structured way, to support cognitive processing and to minimize cognitive load.

\subsection{Functionalities}

In the section functionalities (for the selection and development of these functionalities in order to meet cancer patients interaction needs see Arnold/Leimeister/Krcmar 2003, Leimeister/Daum/Krcmar 2002) the services discussion forum / bulletin board, "ask an expert", a contact search for members and chat modules are offered. Further services are provided on each member's personalized starting page: individual interaction services such as an internal mailing- 
system, a guest book, buddy-lists and awareness functions such as "friends online", "users chatting" or "number of members of the krebsgemeinschaft.de" (Fig. 1).

The discussion forum/bulletin board enables an asynchronic exchange between the members. It not only supports communication but also the process of members becoming better acquainted with one another. Further, it enhances the creation and the cultivation of a sense of a community (Blanchard/Markus 2002).

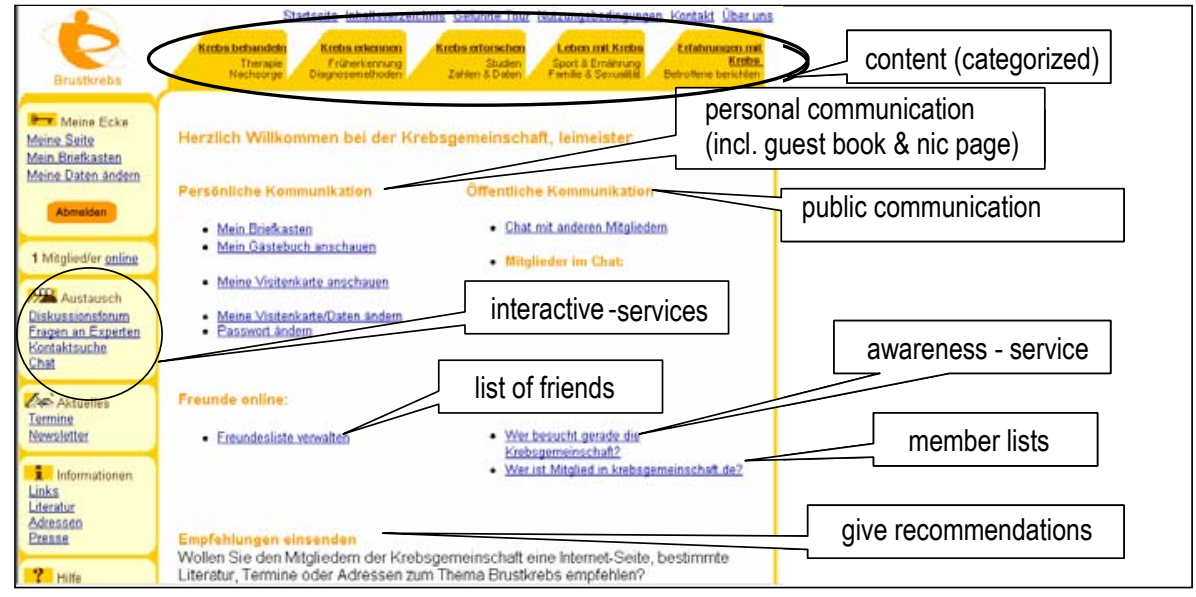

Figure 1: Information and interaction services as well as the personalized starting page for members on www.krebsgemeinschaft.de (Source: Leimeister 2004, p. 201).

The service "ask an expert" is a modified form of a discussion forum where users post their questions and experts (well-known physicians assigned by the community management) answer them. The service is organized in periodic cycles; each cycle has a featured focus and a prominent expert. This reduces the work-load for the responding experts and overall the service is easier to organize. With this service, patients can easily make inquiries without time pressures.

The contact search aims at supporting the members in finding people in similar situations and/or with similar interests. The service is designed to offer an easy possibility for contacting other members. Thus, it furthers direct interaction between members and fosters a community feeling.

The chat offers the possibility to get in contact with other members simultaneously. It is a synchronic real-time communication which requires at least two participants. To increase the probability for meeting other users in the chat room, fixed chat hours were established in the beginning.

Additionally, each member has his or her own space in the community, called nic page and a guest book.

\subsection{Trust supporting components}

In addition to useful functionalities and good information services, the trustworthiness of the offered services is an important success factor of a VC (for empirical findings on success factors of VCs and the special role of trust in this context see Leimeister/Sidiras/Krcmar 2004). In order 
to sustain krebsgemeinschaft.de, we needed to find ways to establish trust systematically. Two major trust-supporting factors are perceived competence and perceived goodwill (Ebner/Leimeister/Krcmar 2004) suggested in the literature as influencing the development of trust (Abdul-Rahman/Hailes 2000).

Perceived competence in the off-line environment is monitored by organizations that investigate and evaluate the reputation of other organizations; for example rating agencies such as Standard \& Poor's or Moody's. These organizations collect and analyze information about business partners and provide a rating schema as a commercial service.

Within the context of online applications, many so-called "trust partners" have been established. As independent organizations, these trust partners guarantee compliance with standards (i.e.: secure payments and encrypted secured data transmission). In the on-line world, examples are "Trusted Shops" at online-platforms such as epinions.com or commercial solutions offered by companies such as Verisign Inc. Through continuous examination of, for example, the handling of privacy regulations, these institutions support the development of trust. They may also force business partners to adhere to standards in order to ensure that customers receive the goods and/or services they expect (Shneiderman 2000).

There are several factors that can positively influence perceived competence and perceived goodwill. Perceived competence can be supported by clear definitions of the various responsibilities of the individuals providing goods or services. The disclosure of all prices, delivery times, taxes or cancellation fees is meant to be an advantage for the buyer or consumer. Binding terms of use and codes of behaviour are applied accordingly.

A further indicator to support perceived competence is the disclosure of patterns of past performance. Examples include airlines' reports on on-time percentages for arrivals and departures or realtors' statistics on the number of houses bought and sold. The disclosure of performance reports may attract users, as does information about the organization and its management. Even sceptical consumers may be engaged and assured by the transparency of performance numbers (Shneiderman 2000).

Perceived goodwill is more difficult to describe. It can be experienced as the discovery of a cooperating partner's good intentions and can further lead to the development of interpersonal trust. Examples in the off-line world often refer to aspects such as common courtesy and complimentary behaviour of market partners when, for example, a customer's complaint is handled in favour of the client without legal necessity to do so.

In accordance with the existing literature on trust, the rationale here was to develop a set of components that affect both perceived goodwill and perceived competence in a positive manner. Hypothetically, the two constructs should consequently have a positive affect on trust.

A set of trust-supporting components for the $\mathrm{VC}$ consists of a transparent provider concept (who is providing the service and what is his motivation to do so), an adequate access right concept and reasonable role models (which tasks and roles exist within the $\mathrm{VC}$, who is taking care of them and which set of authorization does each actor have), an anonymity concept (each user should be able to determine independently how much of his private data he wants to share with other users) and the usage of trust-seals. For this purpose, the trust seal promoted by the German Federal Health Ministry afgis (Health Information System Action Forum, http://www.afgis.de/index.php?lang=e) was used for krebsgemeinschaft.de. For further 
information concerning the development and design of the trust supporting components see (Ebner/Leimeister/Krcmar 2003, 2004; Leimeister 2004). Figure 2 visualises selected trust supporting components as used on an individual member page of krebsgemeinschaft.de

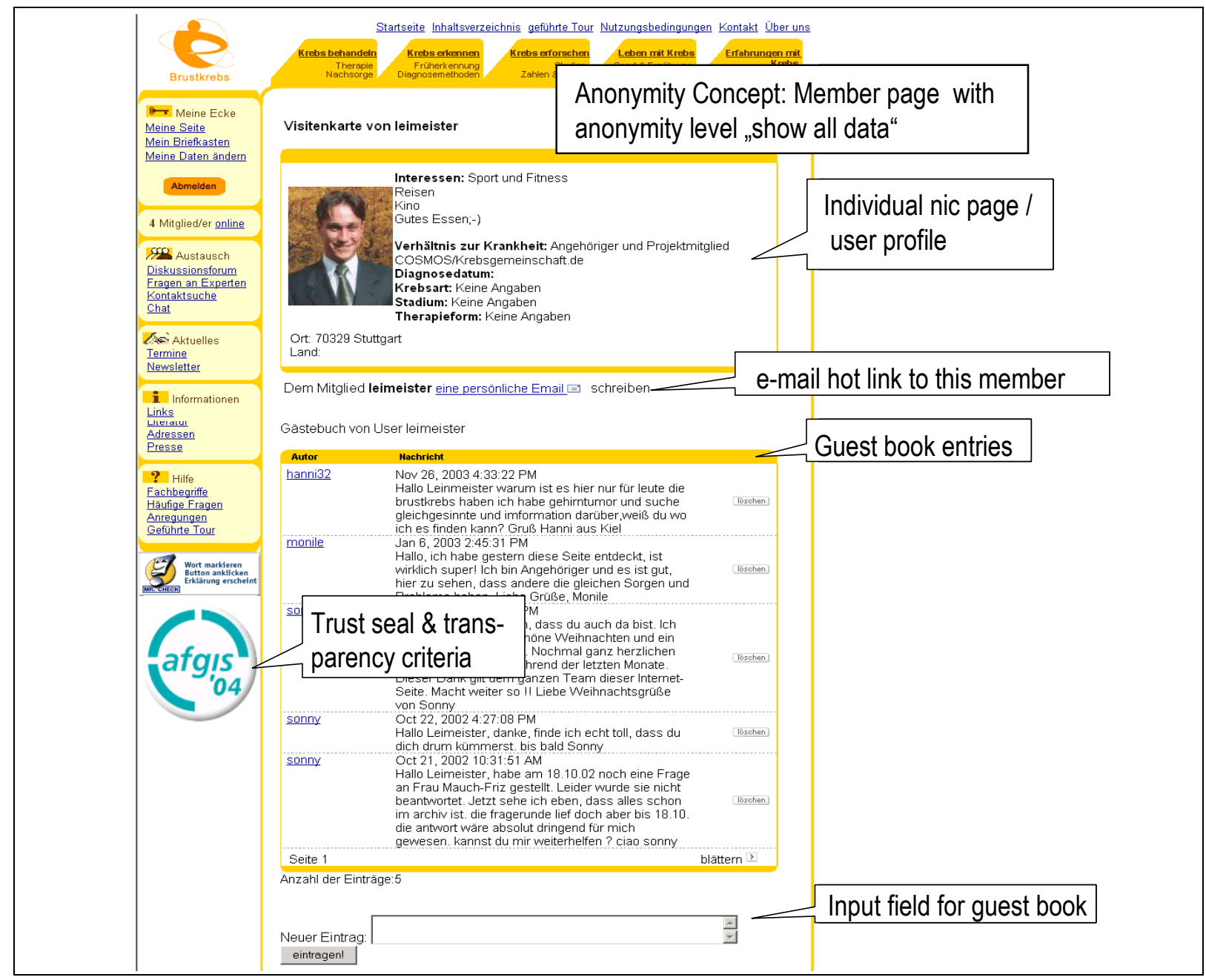

Figure 2: Selected trust-supporting components on personal member page with guest book (anonymity level "show all data") on www.krebsgemeinschaft.de (accessed March 29 $9^{\text {th }} 2005$ )

Another important factor is community management. Although it is usually associated with activities of community development and community cultivation (for additional information on the role of community management see Holmström/Henfridsson 2002), strong and diligent management of the community may play a role in establishing trust during the early stages of initiation of a VC. Community management activities include ensuring an attractive activity level in the community through encouraging member interaction and through own activity until a critical mass of users has been reached. During the operation of the VC, community management should assure that rules and norms of the VC are adhered to through, for example, moderation of the boards. This aspect of community building has been sparsely researched to date. 
In the following we briefly outline the design principles "usability" and "accessibility" as they influence all other design elements at all stages of community building.

\subsection{Usability}

Potential users of services on the internet decide within seconds whether they want to use them or not, thus the usability of services and sites is of major importance. Aspects such as layout, colour, graphics, and scripts play an important role. These aspects are often subsumed under the term usability. Usability is always context- and usage-specific: there are no generally valid rules for creating usability. Usability and overall impression have a strong influence on whether websites appear trustworthy and credible (Fogg et al. 2002). From the different usabilityprinciples (Mannhartsperger/Linder/Zellhofer 2003, pp. 17), one can derive the following metaprinciples:

Adequacy of a task: a dialogue with a system is adequate if it supports the execution of the task of the user without burdening him with unnecessary details (e.g. form the dialogue system).

Conformity with the expectations: a system's behaviour conforms to expectations if each element / each part of the system represents that part of the design and content that the user expects.

Consistency: a uniform appearance of a system within one context is named „consistency“. Consistency is crucial for usability because the user can rely on already learned patterns und does not have to adapt to new systems. Consistency is one of the most important usability principles (Mayhew 1992) and leads to usability (Spolsky 2001; Nielsen, 2002).

Visibility: Well-designed human-machine interfaces have easily visible control elements. Each control element (knob, button, etc.) controls optimally only one function (Norman 1988, 1992).

\subsection{Accessibility}

As the internet ensures the transmission of information in form of text, it can easily be accessed by users with physical handicaps. The usage of one sense organ can be replaced by the usage of another (WEBforALL 2003a). This attribute of internet-based information gathering is especially important for target groups such as cancer patients because of restricted micro mobility and other physical handicaps incurred as a result of treatment or the disease itself. However, different kinds of barriers can exist on websites. They are created by the use of specific configurations and designs and might limit handicapped people from adequately accessing the services.

Since May $1^{\text {st }} 2002$, German government web sites as well as all graphical user interfaces provided by them have to be designed in a way that handicapped persons can use them unrestrictedly. A barrier free internet site is easily readable and navigatable with available tools for handicapped users. To achieve barrier free internet sites, various providers have developed specific design guidelines (e.g. (WEBforALL 2003b)). 
Another relevant component of successful community building can be assigned to the role of community management during the initiation and operation of a VC.

\section{Evaluation of the systematic design of krebsgemeinschaft.de- addressing acceptance, utility and trust}

The objective of this section is to assess the outcome of the systematic design as applied in the case of krebsgemeinschaft.de in order to answer the following questions:

- Was the community building successful?

- What findings can be derived for the systematic design / community building?

Combining qualitative and quantitative methods can improve the capacity of evaluation findings significantly. This triangulation of methods has some tradition in IS research (Gallivan 1997). In order to achieve best possible results we used both quantitative and qualitative methods to answer the research questions.

\subsection{Evaluation criteria and methods}

To evaluate the efficacy of the design components used during the development of krebsgemeinschaft.de it was necessary to identify criteria for the success of each single component and to determine the sum of all components. Measuring success and identifying a cause-effect chain for single components is extremely difficult as it is often not possible to isolate the effect of a single measure on the user. Frequently only the sum of all actions and influences is assessable. Figure 1 illustrates the previously mentioned design components and their cumulative effect on the success respectively the acceptance and usage of the VC krebsgemeinschaft.de.

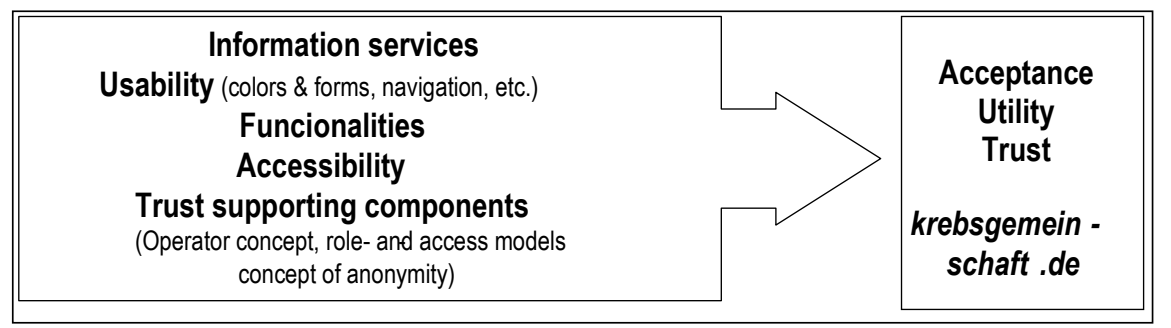

Figure 3: Intended cause-effect chain between design components and usage, utility and trust in the case of krebsgemeinschaft.de (Source: Leimeister 2004)

Specific indicators for the success of VCs can be found on different levels, given, however, that there is a lack of systematic approaches and operational suggestions for measuring the success of VCs. We applied evaluation techniques from both classical social research and online research, especially log file analyses, online surveys, document analysis and observations. These techniques were applied to the case of the VC krebsgemeinschaft.de and all data refer to the 
period from 19.08.02 to 22.05.03 as long as no other information is given. We began with the quantitative analysis of the server log files, and then analyzed the online member surveys. Finally several archive analyses were conducted and observations were analysed.

\subsection{Empirical findings}

\subsubsection{Performance measures for the evaluation of interactive elements within the community}

The core of a VC is the interaction of its members which mainly occurs either in the chat rooms or the discussion forums/bulletin boards. For the measurement of the "member-to-member interaction" the following criteria were used (adapted from Cothrel 2000, p. 18).

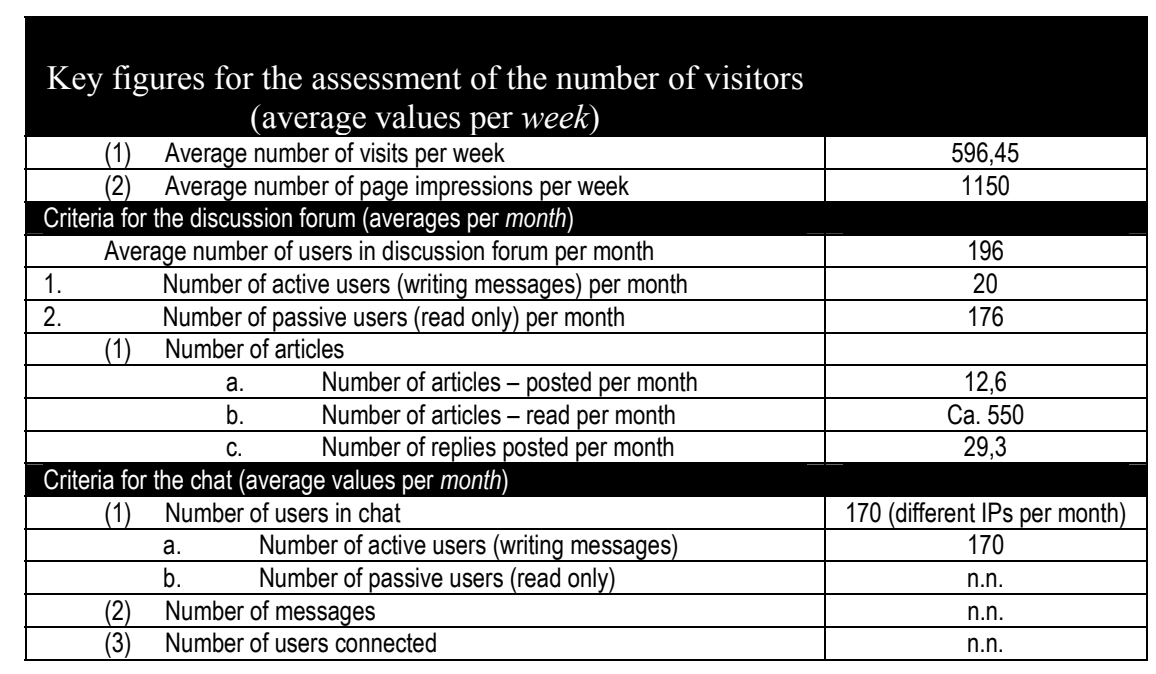

Table 1: Key data for the usage of krebsgemeinschaft.de during the period 08/2002-12/2004.

Log-file analyses and their purely quantitative values are not sufficient for evaluating a VC. A small number of active users (such as those in krebsgemeinschaft.de) contribute more to the „life“ of a community than a much greater number of passive users, so called ,lurkers“ (Nonnecke/Preece 2000). For that reason, we used qualitative analyses in the form of member surveys, observations and archive analyses. All empirical findings were compared and triangulated.

\subsubsection{Usage of services}

We focused on the usage of the different components of krebsgemeinschaft.de. We started with analyses of the usage of the edited and quality assured content. After that we analysed the users' behaviour concerning the interaction services (chat, forum, ask experts, contact search).

Usage of the edited content - Content categories (top level): The graphical presentation and positioning of the content on the website is presented in Figure 1. The content categories and their arrangement were chosen in correspondence with their expected importance as found in other media and services for cancer patients. The top-level content categories (designed as index- 
cards) with the categories cancer treatment, identifying cancer, cancer research, living with cancer and experiences with cancer were arranged in seceding order from left to right.

For all content categories (index cards) a similar development of the user numbers could be observed. The user numbers declined after the first weeks followed by a ground-building process on a more or less stable level. Relatively high values could be seen in the last month of observation in the categories "cancer treatment" and "living with cancer" (contradicting the assumption that living with cancer should be ranked four in interest). These topics seemed to be of exceptional interest for the users of krebsgemeinschaft.de. As the editorial content had not changed for a longer period of time, it could be assumed that visitors who already visited the sites several times had saturated their demand for information on those pages and left them out during later visits. Additionally, only a few "new" members registered in the VC during the analysed period. This could be an explanation for the declining number of users in this section. The total decline could be a first hint for the existence of an individual member life-cycle that correlates with an individual information-demand curve, which could depend on the phase of illness or the time elapsed since the diagnosis.

Interaction services: The analysis of the development of the single interaction services showed clearly that especially the contact search had rarely been used. The reason for this might be that right after the launch of the platform, a group building process among the new members had started. In consequence, many users did not have experience difficulty finding others since they were already integrated into a newly emerging group. On the other hand, a reason could be the poor implementation of the service. Within the framework of the user surveys, it was mentioned by several respondents that the contact search was not working as it should or it functioned too slowly.

Discussion forum/bulletin board: The discussion forum was a frequently used service of krebsgemeinschaft.de. 367 entries were posted during the evaluation period. Thereof 114 were new threads and 253 were replies to these threads. That means that there was more than an average of two replies per request whereas the number of answers varied between 0 (often no answer was expected for example in the case of pure hints to lectures, expert rounds or similar items) and 9. Most commonly the answers were directly connected to the question. Only exceptionally did a discussion emerge that lost its connection to the initial posting. To evaluate which issues were discussed in the discussion forum, a content analysis of the threads and replies was conducted. Basically two main thematic blocks could be identified: Postings that stated a rather factual demand for information and emotional postings that asked for emotional support from other members and showed a wish for integration into a community as well as for empathy. Often the two categories could not be separated as some of the requests for information were often phrased in an emotional way. Examples were questions about the loss of hair after chemotherapy or breast reconstruction.

In summary, the discussion forum was mainly used to share individual experiences with others and to learn from the experiences of others. The major part of the communication threads has to be assigned to the "factual" category, although a high percentage of these postings also exhibited emotional aspects. More striking was that very intimate and personal postings were made in the forum. Members spoke honestly and openly about their feelings and personal experiences. It should be kept in mind that the content generated during the first month after the 
launch was made by only a few members who were engaged very intensively in krebsgemeinschaft.de.

Nic pages and guest books: The anonymity concept of krebsgemeinschaft.de offered the members the possibility to decide which personal data they wanted to reveal to the other members of the community by means of their personal nic page (non-registered users/visitors do not see any member data). The members have four choices of anonymity levels: Show nothing (other members will see the note: „The member does not want to show its data."), anonymized (displayed: user name, state, status, kind of relationship to the illness, date of diagnosis, kind of cancer, stadium of the disease, form of therapy, hobbies, interests), anonymized but show all to friends (members of a users' buddy list can see all available user data, other members see the data available on the anonymized level), and finally the level show all (displaying all available data of the user. The nic page is situated above the guestbook of the member and can be accessed by clicking on the user name at any place within the VC.

In May 2003 there were 634 active guestbooks in krebsgemeinschaft.de. 273 (43.1\%) chose „show nothing“, $272(42.9 \%)$,,anonymized”, 9 (1.4\%) ,generally anonymized and show all to friends" and $80(12,6 \%)$ displayed all data to all members of the VC. A strong correlation between the degree of anonymity and the number of entries in the guestbook could be identified: While 273 owners of a guestbook with the anonymity level "show nothing" only received 30 entries; the 272 guestbooks with the nic page configuration "anonymized" received 217 entries. The 80 guestbooks in the "show all" category made up for a total of 383 entries and the 9 guestbooks with the level "anonymized but show all to friends" had 3 entries.

These data seems to indicate that openness could be a major precondition for the functioning of the VC. The more data other members can see, the more entries they post. If members show openness and trust by revealing their identity, they will be rewarded by receiving more postings in their guest books. This is backed up by the construct of "reciprocity" (Preece 1999, 2000; Preece/Maloney-Krichmar 2003). According to this principle, the provision of information to the community is a catalyst for receiving information and reaction from the community and from other members.

It is important to note that the distribution of the guestbook entries was asymmetric. On the one hand, some guestbooks did not have any entries while those of some very active members in krebsgemeinschaft.de had more than 40 entries.

This result, as well as the fact that many of the entries in the discussion forum were posted by a few members, indicates that a small but very active community of members emerged. This group heavily contributed to the life within the community and krebsgemeinschaft.de seemed to play a vital role in their real lives.

The relationships of these active members to each other seemed to be very close and the interaction between them exceeded the limits of the VC and extended into their everyday "real" lives. These members cared very much about the situation and the problems of other active members and tried to support each other.

\subsubsection{Member surveys: Acceptance and utility of krebsgemeinschaft.de}

From quantitative analyses one can not easily derive conclusions about the individual usage and usability of the platform. It is even more difficult to gain insights into the utility for users 
created by their usage of a single specific service within krebsgemeinschaft.de. For the purpose of this article, we define usage as the frequency of usage of specific services as declared by the respondent. Following the design components of the VC the usage behaviour was analysed for both information and interaction services. Both spheres were addressed with closed- and openended questions. We define utility as the subjective impression of the respondents concerning advantages they received from using krebsgemeinschaft.de. This aspect was also addressed in member surveys using open- and closed-ended questions. The survey instrument is added in the appendix.

Overall evaluation: The participants in the survey assessed the design of krebsgemeinschaft.de as positive (Figure 2). This is not surprising when considering the fact that most respondents were using the service intensely. A frequent usage itself can be seen as a positive assessment of the service.

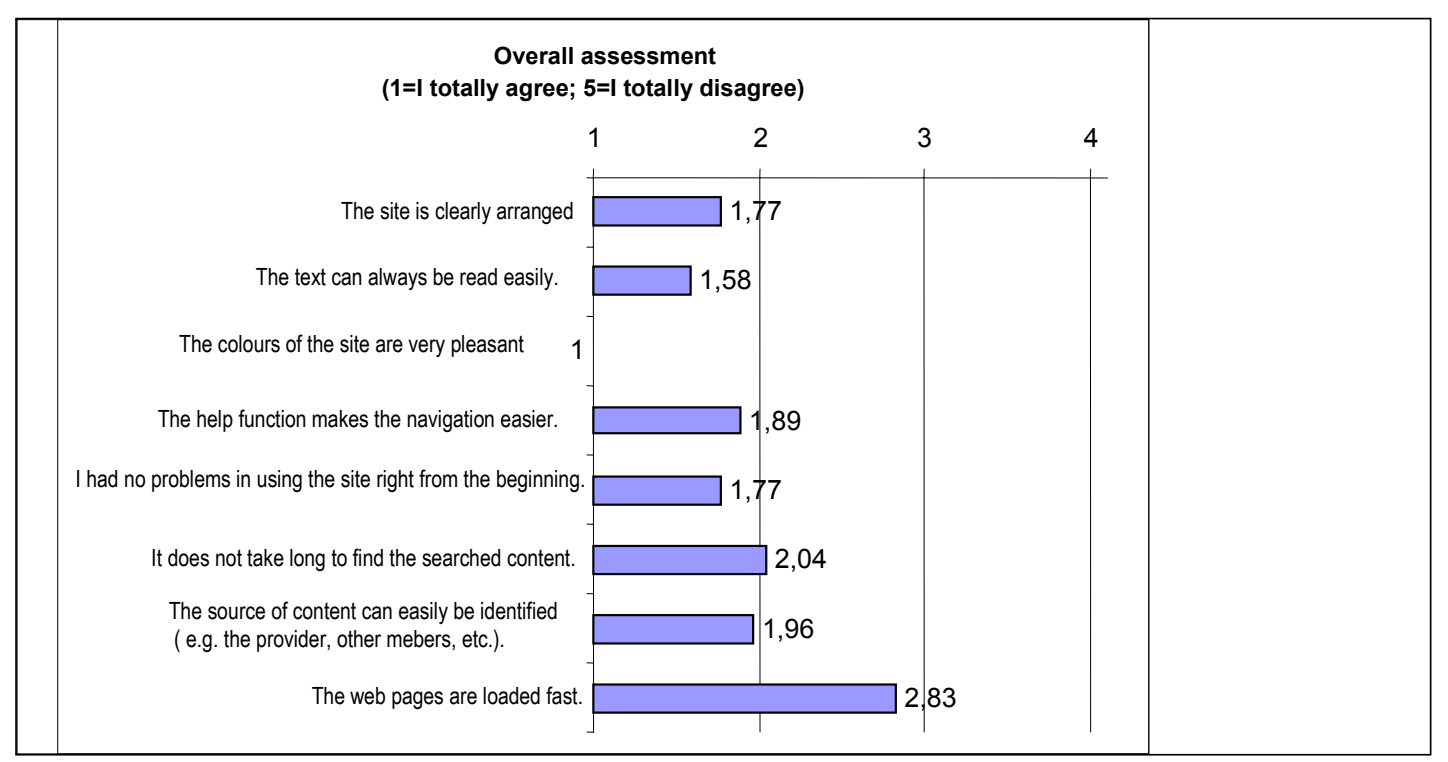

Figure 4: Overall evaluation of krebsgemeinschaft.de $(\mathrm{n}=27)$ (Source: Leimeister/Krcmar 2005)

On average, the users agreed that the site was clearly structured, easily readable, and that the searched content could be easily found. Especially the coloured design was perceived as positive. The users were aware who was providing which content. The loading time and the technical performance of the platform were rated worse.

Correlation between usage of different services and duration of membership in krebsgemeinschaft.de: The data shows a relation between the length of membership and the usage behaviour concerning the usage of information services. $55.5 \%$ of those who were members for less than six months reported using the information services „each time" they visited the VC. Comparatively, only $40 \%$ of those persons with memberships longer than 6 months used these pages this frequently. A conclusion could be that the subjective importance of the information service declines during length of membership.

An even clearer correlation exists between the „duration of membership" and the usage of interactive services. The usage of these services increased significantly during the membership. 
$38.5 \%$ of those who were members for more than 6 months used them "each time" whereas none of the users with less than 6 months membership chose that answer.

The findings are indicators for an individual membership life cycle which becomes manifest in different usage levels of the system. It can be assumed that new members exhibited a high demand for "hard facts" as their diagnosis was more recent than it was with older members. As time elapsed, the users' knowledge became more extensive and therefore the need to use the information services was not as relevant. The usage of the interactive services shows an inverse development. The longer the person was a member, the more intense the feeling of community and the usage of the interactive services became.

Utility: The analysis of the direct question about the felt utility of krebsgemeinschaft.de revealed two major reasons for using the $\mathrm{VC}$ : On the one hand the site offered professional knowledge about cancer and on the other, what seems to be even more important, the users could establish contact to other persons in similar situations. Respondents declared that social relationships and empathy could easily develop. These findings are similar to the results of the analysis of the forum postings. Furthermore, the members said they could easily integrate emotionally in a community and support each other. This is evident by the establishment of regular meetings in "real" life.

The following answer to the question "how has the membership in krebsgemeinschaft.de changed your situation" exemplifies the importance of the service:

„The interchange with others is very beneficial for me. Especially right after the diagnosis all people (family, job) assume that life goes on as before. That's wrong!! Of course you don't want to speak all the time about your (bad) mood and your medical status and somehow no one wants to hear it all the time. Therefore the interchange with other patients is important: You get the mental support you need and it is good to know you're not the only person struggling with such a situation. And it is very impressing and supportive to read how other women can cope with the situation. That resurrects your own will to fight and helps you to cope with the healing process or even medical set-backs."

\subsubsection{Existence of trust in krebsgemeinschaft.de}

During the conception and implementation of krebsgemeinschaft.de trust supporting elements were designed and implemented in the VC (Leimeister/Ebner/Krcmar 2005). The process of trust building should be supported by these components in order to contribute to the establishment of a community. The results of an online-survey intended to measure trust prevailing within the community seemed to certify the success of the trust building components. Both the trust in the providers of krebsgemeinschaft.de (especially in their expertise) and the trust in the other members (especially in their benevolence) seemed to be high.

The behaviour of the questioned members fits well to this finding: They were prepared to use information provided by the community as well as to provide their own knowledge and experiences to the other members. They stated clearly that they trusted the secure treatment of their data and the quality of the provided information. Furthermore it could be proved that a large proportion of the questioned members were acting according to their statements made in the surveys (Leimeister 2004). 
Observations and archive analyses indicated that members candidly and empathically interact with one another, especially via the discussion board and the chat. The log-file analyses and the user numbers (by July 2004 krebsgemeinschaft.de had more than 1000 registered users) underline the success of the project. The design measures seem to have had a positive impact on perceived competence and perceived goodwill of the operators. Similar results were found concerning perceived goodwill of the other members, but slightly lower levels were reported for the perceived competence of other members. Additionally, the data revealed that the respondents reported relatively high levels of trust in the operators and relatively lower levels (but from an absolute perspective still high levels) of trust in other members of the VC. These data support the underlying theoretical constructs by showing that the elements of the design measures had an impact on perceived competence and perceived goodwill. Furthermore, one can derive from the differences of reported trust and perceived competence (especially of other members) that the cause and effect relationship between perceived competence, perceived goodwill, and trust as presented in the literature was supported.

Artefacts of usage as well as the results of extensive observations comply with this result: Members are willing to use information provided by other members and disclose personal experiences within the community. They demonstrate trust that this information will not be misused and that information and data provided by other members is trustworthy and correct. As verification of this, respondents indicated that they based real-life actions on information gathered in the community.

The archive analyses give a clear impression of the motivation for using krebsgemeinschaft.de, of the personal benefit for the users, and of the role trust plays in the VC.

\section{Discussion and Conclusion}

The evaluation of krebsgemeinschaft.de has revealed various findings. First of all, krebsgemeinschaft.de can be rated as a successful VC. Criteria underlining this are:

- An increase in registration numbers ;

- Development of a stable highly active core community;

- Development of an extended community with passive members (lurkers);

- Evidence of the existence of the reciprocity-principle inside the core community in terms of the vivid exchange of information, empathy and support.

- Communication was characterized by a high degree of empathy and trust towards both the provider and the other members.

- Conception of trust supporting components seemed to produce the desired outcome.

- Violations against the rules of the community or incidents that could be categorized as rude or impolite were very low.

- Active members were very content with the social interaction within the VC.

- Strong loyalty ties to krebsgemeinschaft.de apparent as most first-day-members remained active in the community

Concerning the demand-coverage of the community platform, most members seemed to be satisfied, though different functions were rated quite differently. 
Furthermore it could be seen that the design (e.g. the GUI and the design of functionalities) was mainly assessed as user-friendly and good. However, the surveys showed that some of the VCs characteristics were not known by some members and therefore were not used by them (e.g. the anonymity concept or the contact search). Moreover it revealed that the technical reliability of the platform was more important to the members than sophisticated services or functionalities. Although technical equipment was not a limiting factor, conception of a service was much more important for the success of this VC. This was obvious through the very different usage of the service ,ask the experts": By means of shorter reply times and qualitative high and easy understandable answers, the utility and frequency of usage of the service were increased immensely.

The evaluation showed the unique role of qualitative valuable content as an asset for attracting potential users. Another critical success factor in building this $\mathrm{VC}$ was the role of the community management which ensured activity and attractiveness until the critical mass of users had been reached.

The evaluation showed that there was a shift in the information and interaction demands depending on the duration of membership. The desire for interaction and an appreciation for it seemed to increase with ongoing membership.

These results must be seen in light of the study's limitations. The study sample consisted of members of krebsgemeinschaft.de; those who visited the site but decided not to become members were lost to possible inclusion in the study. The inclusion of non-members could have provided valuable data for testing the effect of the design measures and the underlying concepts: Was it an issue of trust that made them decide not to become members? In reality, it would have been difficult to gain access to anyone who visited the site but did not join. Interestingly, the log file analyses of krebsgemeinschaft.de showed a low rate of one-time-visitors, regardless of which criteria proposed for VCs in the literature is applied (Cothrel 2000).

Consequences for further research -The findings of this explorative research need further empirical substantiation and should be compared with other types of VCs in order to improve the validity of the results. It would be of interest to compare the findings of this in-depth case study to other high involvement VCs or to other domains for VCs outside the healthcare realm. A quantitative research model could be developed on the basis of the findings of this research and the theoretical foundations for virtual communities could be expanded.

Additionally, there are several chances and challenges for VCs created by new technical possibilities. Ubiquitous access to VCs through mobile digital devices as well as new (mobile and context sensitive) services for VCs are potentially very rewarding (e.g. an emergency system for cancer patients with a locating service or a mobile pill reminder). The relevance of these ideas for VCs cannot yet be assessed from the current situation.

Furthermore, there is a need for research on the role and tasks of community management. There is a lack of substantial work on supportive administration tools, especially if a community manager administrates several communities, for efficient and effective management.

The analysis of social interactions within VCs and the effects on the social network of the members have yet to be fully investigated. Research on the exact utility of healthcare oriented VCs seems to be especially promising when focussing on the measurement of the VC's influences on the perceived quality of life. 
Recapitulating, the result of this article is empirical proof that the chosen approaches for usercentric development, implementation and operation of a VC for cancer patients within the German healthcare system lead to the desired outcomes. It conveys a rich understanding of the multi-interdependent influences on Virtual Communities in general and contributes to a better understanding of community building for patients.

\section{References}

Abdul-Rahman, A.; Hailes, S. (2000): Supporting Trust in Virtual Communities. In: Proceedings of the 33rd Hawai'i International Conference on System Sciences (HICSS 33), January 4-7, 2000, Maui, Hawai'i.

Arnold, Y.; Leimeister, J. M.; Krcmar, H. (2003): COPEP: A Development Process Model for a Community Platform for Cancer Patients. In: Proceedings of the XIth European Conference on Information Systems (ECIS), Naples.

Bahrs, O.; Klingenberg, A. (1995): Die Beurteilung ärztlicher Arbeit durch Teilnehmer von Selbsthilfegruppen. In: Stand und Zukunft der Qualitätssicherung in der Allgemeinmedizin. Eds.: Szecsenyi, J.; Gerlach, F., Hippokrates, Stuttgart 1995.

Bilodeau, B. A.; Degner, L. F. (1996): Information needs, sources of information, and decisional roles in women with breast cancer. In: Oncology Nursing Forum, Vol. 23 (1996), No. 4, P. 691-696.

Blanchard, A. L.; Markus, M. L. (2002): Sense of Virtual Communtiy--Maintaining the Sense of Belonging-. In: Proceedings of the 35th Hawai'i International Conference on System Sciences (HICSS 36), January 2002, Big Island, Hawai'i.

Brockopp, D. Y.; Hayko, D.; Davenport, W.; Winscott, R. N. (1989): Personal control and needs for hope and information among adults diagnosed with cancer. In: Cancer Nursing, Vol. 12 (1989), No. 2, P. 112-116.

Cothrel, J. (2000): Measuring the success of an online community. In: Strategy \& Leadership, Vol. 28 (2000), p. 17-21.

Daum, M.; Klein, A.; Leimeister, J. M.; Krcmar, H. (2001): Webbasierte Informations- und Interaktionsangebote für Onkologiepatienten - Ein Überblick. Arbeitspapier No. 109. Universität Hohenheim, Lehrstuhl für Wirtschaftsinformatik, Hohenheim 2001.

Derdiarian, A. (1987): Informational needs of recently diagnosed cancer patients. A theoretical framework. Part 1. In: Cancer Nursing, Vol. 10 (1987), No. 2, p. 107-115.

Deutsche_Krebshilfe (2003): Krebs: Zahlen, Daten, Fakten. In: http://www.krebshilfe.de/ neu/medieninfos/zahlen daten fakten.htm, accessed on 29.10.2004

Dierks, C.; Nitz, G.; Grau, U. (2003): Gesundheitstelematik und Recht. Frankfurter Schriften, MedizinRecht.de-Verlag, Frankfurt a. M. 2003.

Döring, N. (2003): Sozialpsychologie des Internet : die Bedeutung des Internet für Kommunikationsprozesse, Identitäten, soziale Beziehungen und Gruppen. 2. Edition, Internet und Psychologie, Hogrefe, Göttingen 2003.

Ebner, W.; Leimeister, J. M.; Krcmar, H. (2003): Vertrauen in virtuellen Communities: Konzeption und Umsetzung vertrauensunterstützender Komponenten in der Domäne Healthcare. In: Proceedings of the 6. Internationale Tagung Wirtschaftsinformatik 2003, p. 619-638, Dresden. 
Ebner, W.; Leimeister, J. M.; Krcmar, H. (2004): Trust In Virtual Healthcare Communities: Design And Implementation Of Trust-Enabling Functionalities. In: Proceedings of the 37th Hawai'i International Conference on System Sciences (HICSS 37), January 5-8, 2004, Big Island, Hawai'i.

Ferber, C. v. (Eds.) (1987): Gesundheitsselbsthilfe und professionelle Dienstleistungen: Soziologische Grundlagen einer bürgerorientierten Gesundheitspolitik Springer, Berlin 1987.

Fogg, B. J.; Soohoo, C.; Danielson, D.; Marable, L.; Stanford, J.; Tauber, E. R. (2002): How Do People Evaluate a Web Site's Credibility? Results from a Large Study. In: http://www.consumerwebwatch.org/news/report3_credibilityresearch/stanfordPTL.pdf, accessed on 10.11.2004, Stanford University, Consumer WebWatch, Sliced Bread Design, LLC.

Forbiger, A. (2001): Leben ist, wenn man trotzdem lacht. Heyne, München 2001.

Gallivan, M.J. (1997): Value in Triangulation: A Comparison of Two Approaches for Combining Qualitative and Quantitative Methods. In: Information Systems and Qualitative Research: Proceedings of the IFIP TC8 WG 8.2 International Conference on Information Systems and Qualitative Research, 31st May - 3rd June 1997, Philadelphia, Pennsylvania, USA. Hrsg.: Lee, A.S.; Liebenau, J.; DeGross, J.I. Chapman \& Hall, London 1997, S. 417443.

Hiller, B. (2001): Unkonventionelle Verfahren in der Onkologie : der Informationsbedarf der Anrufer beim Krebsinformationsdienst im Deutschen Krebsforschungszentrum zu Methoden mit bisher unbewiesener Wirksamkeit, Universität Heidelberg.

Hinds, C.; Streater, A.; Mood, D. (1995): Functions and preferred methods of receiving information related to radiotherapy: perceptions of patients with cancer. In: Cancer Nursing, (1995), No. 18, p. 374-384.

Holmström, H.; Henfridsson, O. (2002): Customer Role Ambiguity in Community Management. In: Proceedings of the $35^{\text {th }}$ Annual Hawaiian International Conference on System Sciences (HICSS 35), Big Island, Hawaii.

Kaminski, E.; Thomas, R. J.; Charnley, S.; Mackay, J. (2001): Measuring patients response to received information. In: European Journal of Cancer, Vol. 37 (2001), Supplement 6, p. 387.

Lechner, U.; Schmid, B. F. (2001): Communities - Business Models and System Architectures: The Blueprint of MP3.com, Napster and Gnutella Revisited. In: Proceedings of the $34^{\text {th }}$ Annual Hawaiian International Conference on System Sciences (HICSS 34), Hawaii.

Leimeister, J. M. (2004): Pilotierung virtueller Communities im Gesundheitsbereich Bedarfsgerechte Entwicklung, Einführung und Betrieb. Dissertation, Universität Hohenheim.

Leimeister, J. M.; Daum, M.; Krcmar, H. (2002): Mobile Virtual Healthcare Communities: An Approach To Community Engineering For Cancer Patients. In: Proceedings of the Xth European Conference on Information Systems (ECIS), p. 1626-1637, Gdansk / Poland.

Leimeister, J.M.; Sidiras, P.; Krcmar, H. (2004): Success Factors of Virtual Communities from the Perspective of Members and Operators - an Empirical Study. In: Proceedings of the $37^{\text {th }}$ Hawaiian International Conference on System Sciences (HICSS 37), January 5-8, 2004, Big Island, Hawaii. 
Leimeister, J. M.; Ebner, W.; Krcmar, H. (2005): Design, Implementation and Evaluation of Trust-supporting Components in Virtual Communities for Patients. In: Journal of Management Information Systems, Vol. 21 (2005), No. 4.

Leimeister, J.M.; Krcmar, H. (2005): Acceptance \& Utility of a Systematically Designed Virtual Community for Cancer Patients. Paper presented at the Communities \& Technologies 2005, Milan.

Levenson, R. W.; Ruef, A. W. (1992): Empathy: A psychological substrate. In: Journal of Personality and Social Psychology, Vol. 63 (1992), No. 2, p. 234-246.

Leydon, G. M.et al (2000): Cancer patients' information needs and information seeking behaviour: in depth interview study. In: British Medical Journal, Vol. 320 (2000), No. 7239, p. 909-913.

Lieberman, M.et al (2003): Electronic support groups for breast carcinoma: a clinical trial of effectiveness. In: Cancer, Vol. 4 (2003), No. 97, S. 920-925.

Madara, E. J. (1997): The mutual-aid self-help online revolution. In: Social Policy, Vol. 27 (1997), No. 3, p. 20-27.

Manaszewicz, R.; Williamson, K.; McKemmish, S. (2002): Breast Cancer Knowledge Online: Towards Meeting the Diverse Information Needs of the Breast Cancer Community. In: Proceedings of the Electronic Networking - Building Community.

Mannhartsperger, M.; Linder, J.; Zellhofer, N. (2003): Ergebnisbericht „Usability von Gesundheitsinformationen im Internet“". Interface Consult, Vienna 2003.

Mayhew, D. J. (1992): Principles and guidelines in software user interface design. Prentice Hall, Englewood Cliffs 1992.

McCaughan, E. M.; Thompson, K. A. (1995): Issues in patient care: information needs of cancer patients receiving chemotherapy at a day-case unit in Northern Ireland. In: Cancer Nursing, Vol. 18 (1995), No. 5, p. 374-384.

McPherson, C. J.; Higginson, I. J.; Hearn, J. (2001): Effective methods of giving information in cancer: a systematic literature review of randomized controlled trials. In: Journal of Public Health Medicine, Vol. 23 (2001), p. 227-234.

Mills, M. E.; Sullivan, K. (1999): The importance of information giving for patients newly diagnosed with cancer: a review of the literature. In: Journal of Clinical Nursing, Vol. 8 (1999), No. 6, p. 631-642.

Moeller, M. L. (1996): Selbsthilfegruppen: Anleitungen und Hintergründe. Rororo-Sachbuch : Psychologie aktiv, Rowohlt, Reinbek bei Hamburg 1996.

Nielsen, J. (Ed.) (2002): Coordinating user interfaces for consistency (Reprint from 1989). San Francisco 2002.

Nonnecke, B.; Preece, J. (2000): Lurker Demographics: Counting the Silent. In: Proceedings of the ACM CHI 2000, p. 73-80, The Hague, NL.

Norman, D. A. (1988): The psychology of everyday things. Basic Books, New York 1988.

Norman, D. A. (1992): Turn signals are the facial expressions of automobiles. Addison-Wesley, Reading 1992.

Peppers, D.; Rogers, M. (1997): Enterprises One to One: Tools for Competing the Interactive Age. New York 1997.

Preece, J. (1999): Emphatic communities: balancing emotional and factual communication. In: Interacting with Computers, Vol. 12 (1999), p. 63-77. 
Preece, J. (2000): Online Communities - Designing Usability, Supporting Sociability. John Wiley and Sons, Chichester, New York, Weinheim, Brisbane, Singapore, Tokio 2000.

Preece, J.; Ghozati, K. (2001): Observations and Explorations of Empathy Online. In: Internet and Health Communication: Experience and Expectations. Eds.: Rice, R. R.; Katz, J. E., Sage, Thousand Oaks 2001, p. 237-260.

Preece, J.; Maloney-Krichmar, D. (2003): Online Communities: Focussing on Sociability and Usability. In: Handbook of Human-Computer Interaction. Eds.: Jacko, J.; Sears, A., Lawrence Earlbaum Associates Inc., Mahwah (NJ) 2003.

Rafaeli, S.; LaRose, R. J. (1993): Electronic Bulletin Boards and "Public Goods" - Explanations of Collaborative Mass Media. In: Communication Research, Vol. 20 (1993), No. 2, p. 277 290.

Ruprecht, T. M. (Eds.) (1998): Experten fragen - Patienten antworten : Patientenzentrierte Qualitätsbewertung von Gesundheitsdienstleistungen ; Konzepte, Methoden, praktische Beispiele. Asgard-Verlag, Sankt Augustin 1998.

Schubert, P. (1999): Virtuelle Transaktionsgemeinschaften im Electronic Commerce: Management, Marketing und Soziale Umwelt. Electronic Commerce, Josef Eul Verlag, Lohmar, Köln 1999.

SEKIS (2000): Nutzeranliegen an Patienteninformation - Auswertung des Expertendialogs und der Fragebogenerhebung zum Informationsbedarf aus Patientensicht. SEKIS Selbsthilfe Kontakt- und Informationsstelle, Berlin 2000.

Shneiderman, B. (2000): Designing trust into online experiences. In: Communications of the ACM, Vol. 43 (2000), No. 12, p. 57-59.

Shuyler, K. S.; Knight, K. M. (2003): What Are Patients Seeking When They Turn to the Internet? Qualitative Content Analysis of Questions Asked by Visitors to an Orthopaedics Web Site. In: Journal of Medical Internet Research, Vol. 5 (2003), No. 4.

Spolsky, J. (2001): User interface design for programmers. Apress, Berkeley 2001.

WEBforALL (2003a): Die Bedeutung des Internets für Behinderte. In: http://www.webforall.info/html/deutsch/bedeutung_des internet.php, zugegriffen am 10.11.2003, VbI e.V. - Vereins zur beruflichen Integration und Qualifizierung e.V.

WEBforALL (2003b): Empfehlungen für ein barrierefreies Webdesign. In: http://webforall.info/html/deutsch/empfehlungen.php, zugegriffen am 10.11.2003, VbI e.V. - Vereins zur beruflichen Integration und Qualifizierung e.V.

Zemore, R.; Shepel, L. F. (1987): Information Seeking and Adjustment to Cancer. In: Psychological Reports, Vol. 60 (1987), p. 874.

Ziegler, G.; Müller, F.; Grünwald, W. (1986): Psychische Reaktionen und Krankheitsverarbeitung von Tumorpatienten - weitere Ergebnisse. In: Zeitschrift für Psychotherapie und medizinische Psychologie, Vol. 36 (1986), No. 150-158.

Ziegler, G.; Pulwer, R.; Koloczek, D. (1984): Psychische Reaktionen und Krankheitsverarbeitung von Tumorpatienten. In: Zeitschrift für Psychotherapie und medizinische Psychologie, Vol. 34 (1984), p. 44-49. 


\section{Appendix}

\section{Extract of Survey (original \& translation in italics)}

\section{$[\ldots]$}

Nutzung der Informationsangebote von krebsgemeinschaft.de

Usage of the information services of krebsgemeinschaft.de

6. Wie häufig nutzen Sie die folgenden Angebote, wenn Sie sich in der krebsgemeinschaft.de aufhalten?

6. How often have you used the following sections/services when you have visited krebsgemeinschaft.de

$$
\begin{array}{lllrc}
\text { jedes Mal } & \text { meistens } & \begin{array}{c}
\text { gelegentlich } \\
\text { every time }
\end{array} & \begin{array}{r}
\text { selten } \\
\text { mostly }
\end{array} & \begin{array}{c}
\text { nie } \\
\text { sometimes }
\end{array} \\
\text { seldom } & \text { never }
\end{array}
$$

A) Informationsseiten / Information pages

B) Literaturtipps / Literature tips

C) Terminübersicht / Schedule

D) Visitenkarten / Business cards

$\begin{array}{lll}\square & \square & \square \\ \square & \square & \square \\ \square & \square & \square \\ \square & \square & \square\end{array}$

7. Vermissen Sie Informationen zu bestimmten Themen? Wenn ja, zu welchen?

7. Do you feel that some information is missing? If yes, to which topics?

8. Inwieweit stimmen Sie den folgenden Aussagen über die Informationen auf krebsgemeinschaft.de zu? 
8. To which extent do you agree to the following statements about information provided on krebsgemeinschaft.de

\begin{tabular}{|c|c|c|c|c|c|}
\hline & $\begin{array}{l}\text { Ich voll und ganz } \\
\text { stimme zu / } \\
\text { I strongly agree }\end{array}$ & $\begin{array}{l}\text { Ich stimme } \mathrm{zu} / \\
\text { I disagree }\end{array}$ & $\begin{array}{l}\text { Teils teils / } \\
\text { I agree partly }\end{array}$ & $\begin{array}{l}\text { Ich stimme } \\
\text { nicht zu / } \\
\text { I disagree }\end{array}$ & $\begin{array}{l}\text { Ich stimme } \\
\text { überhaupt nicht } \\
\mathrm{zu} / \\
\text { I strongly dis- } \\
\text { agree }\end{array}$ \\
\hline $\begin{array}{l}\text { Viele Informationen sind für mich neu / } \\
\text { A lot of information is new to me }\end{array}$ & $\square$ & $\square$ & $\square$ & $\square$ & $\square$ \\
\hline $\begin{array}{l}\text { Hier erhalte ich mehr Informationen als beim Arzt / } \\
\text { Iget more information than at my doctor's office }\end{array}$ & $\square$ & $\square$ & $\square$ & $\square$ & $\square$ \\
\hline $\begin{array}{l}\text { Die Informationen sind gut verständlich / } \\
\text { The information is comprehensible }\end{array}$ & $\square$ & $\square$ & $\square$ & $\square$ & $\square$ \\
\hline $\begin{array}{l}\text { Die Informationen sind mir nicht ausführlich genug / } \\
\text { The information is not extensive enough }\end{array}$ & $\square$ & $\square$ & $\square$ & $\square$ & $\square$ \\
\hline $\begin{array}{l}\text { Die Informationen sind gut strukturiert / } \\
\text { The information is well structured }\end{array}$ & $\square$ & $\square$ & $\square$ & $\square$ & $\square$ \\
\hline $\begin{array}{l}\text { Die Informationen enthalten zu viele Fachbegriffe / } \\
\text { The information contains too much technical terms }\end{array}$ & $\square$ & $\square$ & $\square$ & $\square$ & $\square$ \\
\hline $\begin{array}{l}\text { Die Informationen sind aktuell / } \\
\text { The information is up-to date }\end{array}$ & $\square$ & $\square$ & $\square$ & $\square$ & $\square$ \\
\hline
\end{tabular}

9. Wie häufig nutzen Sie Ihren Briefkasten, wenn Sie krebsgemeinschaft.de besuchen?

9. How often do you use your internal mailbox, when visiting krebsgemeinschaft.de?

\begin{tabular}{|l|l|l|l|l|l|c|}
\hline & $\begin{array}{l}\text { jedes Mal / } \\
\text { every time }\end{array}$ & $\begin{array}{l}\text { meistens / } \\
\text { mostly }\end{array}$ & $\begin{array}{l}\text { gelegentlich / } \\
\text { seldom }\end{array}$ & $\begin{array}{l}\text { selten / } \\
\text { rarely }\end{array}$ & $\begin{array}{l}\text { Nie / } \\
\text { never }\end{array}$ & $\begin{array}{l}\text { Kenne ich nicht / } \\
\text { I don't know this } \\
\text { function }\end{array}$ \\
\hline eMails lesen / reading eMails & $\square$ & $\square$ & $\square$ & $\square$ & & $\square$ \\
\hline $\begin{array}{l}\text { eMails schreiben / Writing } \\
\text { eMails }\end{array}$ & $\square$ & $\square$ & $\square$ & $\square$ & & $\square$ \\
\hline
\end{tabular}


Warum nutzen Sie die E-Mail-Funktion nicht öfter? (z.B. zu kompliziert, dauert zu lange)

Why don't you use the email function more frequently? (e. g. too complicated, takes too long)

10. Wie häufig nutzen Sie Gästebücher, wenn Sie krebsgemeinschaft.de besuchen?

10. How often do you use Guestbooks, when visiting krebsgemeinschaft.de?

\begin{tabular}{|l|c|c|l|l|l|c|}
\hline & $\begin{array}{l}\text { jedes Mal / } \\
\text { every time }\end{array}$ & $\begin{array}{l}\text { meistens / } \\
\text { mostly }\end{array}$ & $\begin{array}{l}\text { gelegentlich / } \\
\text { seldom }\end{array}$ & $\begin{array}{l}\text { selten / } \\
\text { rarely }\end{array}$ & $\begin{array}{l}\text { Nie / } \\
\text { never }\end{array}$ & $\begin{array}{l}\text { Kenne ich nicht / } \\
\text { I don't know this } \\
\text { function }\end{array}$ \\
\hline $\begin{array}{l}\text { Einträge lesen / reading } \\
\text { entries }\end{array}$ & $\square$ & $\square$ & $\square$ & & & $\square$ \\
\hline $\begin{array}{l}\text { Einträge schreiben / Writing } \\
\text { entries }\end{array}$ & $\square$ & $\square$ & $\square$ & & & $\square$ \\
\hline
\end{tabular}

Warum nutzen Sie die Gästebuch-Funktion nicht öfter?

Why don't you use the guestbook function more frequently?

11. Wie häufig nutzen Sie das Diskussionsforum, wenn Sie krebsgemeinschaft.de besuchen?

11. How often do you use discussion forums, when visiting krebsgemeinschaft.de? 


\begin{tabular}{|l|c|c|c|c|c|c|}
\hline & every time & mostly & seldom & rarely & never & $\begin{array}{l}\text { I don't know this } \\
\text { function }\end{array}$ \\
\hline $\begin{array}{l}\text { Einträge lesen / reading } \\
\text { entries }\end{array}$ & $\square$ & $\square$ & $\square$ & $\square$ & & $\square$ \\
\hline $\begin{array}{l}\text { Einträge schreiben / writing } \\
\text { entries }\end{array}$ & $\square$ & $\square$ & $\square$ & $\square$ & & $\square$ \\
\hline
\end{tabular}

Warum nutzen Sie die Diskussionsforen nicht öfter?

Why don't you use the discussion forum function more frequently?

12. Wie häufig nutzen Sie das Expertenforum, wenn Sie krebsgemeinschaft.de besuchen?

12. How often do you use expert forums, when visiting krebsgemeinschaft.de?

\begin{tabular}{|l|l|l|l|l|l|c|}
\hline & $\begin{array}{l}\text { jedes Mal / } \\
\text { every time }\end{array}$ & $\begin{array}{l}\text { meistens / } \\
\text { mostly }\end{array}$ & $\begin{array}{l}\text { gelegentlich / } \\
\text { seldom }\end{array}$ & $\begin{array}{l}\text { selten / } \\
\text { rarely }\end{array}$ & $\begin{array}{l}\text { Nie / } \\
\text { never }\end{array}$ & $\begin{array}{l}\text { Kenne ich nicht / } \\
\text { I don't know this } \\
\text { function }\end{array}$ \\
\hline $\begin{array}{l}\text { Einträge lesen / reading } \\
\text { entries }\end{array}$ & $\square$ & $\square$ & $\square$ & $\square$ & & $\square$ \\
\hline $\begin{array}{l}\text { Einträge schreiben / Writing } \\
\text { entries }\end{array}$ & $\square$ & $\square$ & $\square$ & $\square$ & & $\square$ \\
\hline
\end{tabular}

Warum nutzen Sie die Expertenforen nicht öfter?

Why don't you use the expert forum function more frequently? 
13. Haben Sie schon einmal die Kontaktsuche genutzt?

13. Did you ever use the contact search?

\begin{tabular}{|c|c|c|}
\hline Ja / yes & Nein / no & Kenne ich nicht / I don't know this function \\
\hline$\square$ & $\square$ & \\
\hline
\end{tabular}

Warum nutzen Sie die Kontaktsuche nicht öfter?

Why don't you use the contact search function more frequently?

14. Wenn Sie schon einmal die Hilfefunktionen auf krebsgemeinschaft.de genutzt haben, waren diese für Sie hilfreich?

14. If you ever used the help functions on krebsgemeinschaft.de, were they helpful to you?

\begin{tabular}{|l|c|c|c|}
\hline & Ja / yes & $\begin{array}{c}\text { Nein / no } \\
\text { Geführte Tour / guided tour }\end{array}$ & $\square$ \\
\hline Häufige Fragen / FAQ & $\square$ & $\square$ & function \\
\hline Fachbegriffe / technical terms & $\square$ & $\square$ \\
\hline Mr. Check / Mr. Check & $\square$ & $\square$ & $\square$ \\
\hline
\end{tabular}

15. Inwieweit stimmen Sie den folgenden Aussagen über das gesamte Angebot auf krebsgemeinschaft.de zu?

15. To which amount do you agree with the following statements about krebsgemeinschaft.de

\begin{tabular}{|l|l|l|l|l|l|l|l}
\hline & $\begin{array}{l}\text { Ich voll und ganz } \\
\text { stimme zu / } \\
\text { I strongly agree }\end{array}$ & $\begin{array}{l}\text { Ich stimme zu / } \\
\text { I disagree }\end{array}$ & $\begin{array}{l}\text { Teils teils / } \\
\text { I agree partly } \\
\text { nicht zu / } \\
\text { I disagree }\end{array}$ & $\begin{array}{l}\text { Ich stimme } \\
\text { überhaupt } \\
\text { nicht zu / }\end{array}$ \\
\hline
\end{tabular}




\begin{tabular}{|c|c|c|c|c|c|}
\hline & & & & & $\begin{array}{l}\text { I strongly dis- } \\
\text { agree }\end{array}$ \\
\hline $\begin{array}{l}\text { Die Seiten sind übersichtlich I } \\
\text { The page is concice }\end{array}$ & $\square$ & $\square$ & $\square$ & $\square$ & $\square$ \\
\hline $\begin{array}{l}\text { Die Schrift ist immer gut lesbar I } \\
\text { The page is well-readable }\end{array}$ & $\square$ & $\square$ & $\square$ & $\square$ & $\square$ \\
\hline $\begin{array}{l}\text { Die Farben der Seiten sind angenehm / } \\
\text { The colouring is pleasant }\end{array}$ & $\square$ & $\square$ & $\square$ & $\square$ & $\square$ \\
\hline $\begin{array}{l}\text { Die Erklärungen (Hilfe) helfen mir, mich zurecht zu finden I } \\
\text { The explanations (help functions) help me to navigate on the } \\
\text { site }\end{array}$ & $\square$ & $\square$ & $\square$ & $\square$ & $\square$ \\
\hline $\begin{array}{l}\text { Es fiel mir von Anfang an leicht, die Seiten zu nutzen I } \\
\text { It was easy to use the site from the beginning }\end{array}$ & $\square$ & $\square$ & $\square$ & $\square$ & $\square$ \\
\hline $\begin{array}{l}\text { Es dauert nicht lange, gewünschte Inhalte zu finden I } \\
\text { It doesn't take long to find the desired content }\end{array}$ & $\square$ & $\square$ & $\square$ & $\square$ & $\square$ \\
\hline $\begin{array}{l}\text { Es ist leicht ersichtlich, von wem welche Informationen } \\
\text { stammen (z.B. Team der Krebsgemeinschaft, andere } \\
\text { Mitglieder, Experten...) I } \\
\text { The author of a certain information is clearly visible (e. g. team } \\
\text { of krebsgemeinschaft.de, other members, experts....) }\end{array}$ & $\square$ & $\square$ & $\square$ & $\square$ & $\square$ \\
\hline $\begin{array}{l}\text { Die Seiten werden schnell angezeigt } / \\
\text { The sites are rapidly loading }\end{array}$ & $\square$ & $\square$ & $\square$ & $\square$ & $\square$ \\
\hline
\end{tabular}

16. Wenn Sie krebsgemeinschaft.de besuchen, was ist Ihnen hierbei besonders wichtig?

16. When visiting krebsgemeinschaft.de, what's especially important to you?

\begin{tabular}{|l|l|l|l|}
\hline & $\begin{array}{l}\text { Sehr wichtig } \\
\text { Very important }\end{array}$ & $\begin{array}{l}\text { Wichtig / Important } \\
\text { Impht }\end{array}$ & $\begin{array}{l}\text { so } \\
\text { wichtig / } \\
\text { Rather } \\
\text { unimportant }\end{array}$ \\
$\begin{array}{l}\text { Ich kann anonym bleiben I } \\
\text { I can stay anomynous }\end{array}$ & $\begin{array}{l}\text { Absolutely } \\
\text { unimportant }\end{array}$ \\
\hline $\begin{array}{l}\text { Die Nutzung ist kostenlos I } \\
\text { Usage is free of charge }\end{array}$ & $\square$ & $\square$ \\
\hline
\end{tabular}




\begin{tabular}{|l|l|l|c|}
\hline $\begin{array}{l}\text { Krebsgemeinschaft.de wird von nichtkommerziellen } \\
\text { Betreibern geführt I } \\
\text { Krebsgemeinschaft.de is a non-commercial site }\end{array}$ & $\square$ & $\square$ & $\square$ \\
\hline $\begin{array}{l}\text { Krebsgemeinschaft.de bietet ein besonderes } \\
\text { Informationsangebot (schnell verfügbar, aktuell, fachlich } \\
\text { fundiert) I }\end{array}$ & $\square$ & $\square$ & $\square$ \\
$\begin{array}{l}\text { Krebsgemeinschaft.de offers a special information supply (fast } \\
\text { accesible, recent, substantial) }\end{array}$ & & $\square$ & \\
\hline
\end{tabular}

Sonstiges / Other

17. Treffen die folgenden Gründe für die Nutzung von krebsgemeinschaft.de auf Sie zu?

17. To what extent do the following reasons for the usage of krebsgemeinschaft.de suit your situation?

\begin{tabular}{|c|c|c|c|c|}
\hline & $\begin{array}{l}\text { Trifft voll und } \\
\text { ganz } \mathrm{zu} \\
\text { True }\end{array}$ & $\begin{array}{l}\text { Trifft eher } \mathrm{zu} / \\
\text { Rather true }\end{array}$ & $\begin{array}{l}\text { Trifft eher } \\
\text { nicht } \mathrm{zu} / \\
\text { Rather false }\end{array}$ & $\begin{array}{l}\text { Trifft überhaupt } \\
\text { nicht zu / } \\
\text { False }\end{array}$ \\
\hline $\begin{array}{l}\text { Ich kann die Seite immer, unabhängig von einer } \\
\text { bestimmten Tageszeit, besuchen / } \\
\text { I can use the site at any time }\end{array}$ & $\square$ & $\square$ & $\square$ & $\square$ \\
\hline $\begin{array}{l}\text { Ich kann die Seite überall, unabhängig von einem } \\
\text { bestimmten Ort, nutzen. I } \\
\text { I can use the site from any place }\end{array}$ & $\square$ & $\square$ & $\square$ & $\square$ \\
\hline $\begin{array}{l}\text { Es ist mir möglich, auch mit Personen in Kontakt zu } \\
\text { kommen, die weit entfernt wohnen I } \\
\text { I can get in touch with people who live far away }\end{array}$ & $\square$ & $\square$ & $\square$ & $\square$ \\
\hline $\begin{array}{l}\text { Es ist mir möglich, mit Personen in Kontakt zu treten, die in } \\
\text { derselben / einer ähnlichen Situation sind wie ich selbst / } \\
\text { I can get in touch with people in the same or a similar situation } \\
\text { to mine }\end{array}$ & $\square$ & $\square$ & $\square$ & $\square$ \\
\hline Andere Mitglieder sagen mir ehrlich und neutral, was sie & $\square$ & $\square$ & $\square$ & $\square$ \\
\hline
\end{tabular}




\begin{tabular}{|c|c|c|c|c|}
\hline $\begin{array}{l}\text { denken, da sie nicht durch persönliche Nähe beeinflusst } \\
\text { werden (wie dies z. B. bei Familienmitgliedern oder } \\
\text { Freunden der Fall sein könnte) / } \\
\text { Other members tell me honestly and neutrally what they think, } \\
\text { as they are not influenced by their personal closeness (like e. g. } \\
\text { relatives, friends, etc) }\end{array}$ & & & & \\
\hline $\begin{array}{l}\text { Ich kann bei krebsgemeinschaft.de auch vorbeischauen, } \\
\text { ohne aktiv teilzunehmen I } \\
\text { I can visit krebsgemeinschaft.de without participating actively }\end{array}$ & $\square$ & $\square$ & $\square$ & $\square$ \\
\hline $\begin{array}{l}\text { Ich kann offen über meine Situation und Gefühle sprechen, } \\
\text { ohne mir Gedanken über die Gefühle meines } \\
\text { Gesprächspartners machen zu müssen I } \\
\text { I can talk openly about my situation and my feeling without } \\
\text { thinking about the feelings of my conversational partner }\end{array}$ & $\square$ & $\square$ & $\square$ & $\square$ \\
\hline
\end{tabular}

18. Bitte beschreiben Sie kurz, wie sich die Mitgliedschaft bei krebsgemeinschaft.de auf Ihre Situation auswirkt / ausgewirkt hat (z.B. Sie haben neuen Mut gefasst oder Sie haben hilfreiche Informationen gefunden o. ä.)

18. Please describe shortly how the membership at krebsgemeinschaft.de influences or has influenced your situation (e. g. Did you find new strength or did you find helpful information, etc.)

19. Einmal angenommen, Sie müssten ab morgen für einen Monat auf das Angebot von krebsgemeinschaft.de verzichten. Was würden Sie am meisten vermissen?

19. Hypothetically, if you had to live without krebsgemeinschaft.de for a month. What would you miss the most?

\section{$[\ldots]$}

